\title{
Multiple Linear Regression (MLR) Model: A Tool for Water Quality Interpretation
}

\author{
Ogbozige, F. J ${ }^{1 *}$., Toko, M. $\mathrm{A}^{2}$ and Arawo, C. $\mathrm{C}^{3}$ \\ ${ }^{1}$ Department of Civil Engineering, Federal University Otuoke, Nigeria \\ (*engr.ogbozige@gmail.com). \\ ${ }^{2}$ Department of Water Resources and Environmental Engineering, Ahmadu Bello University, \\ Zaria, Nigeria. \\ ${ }^{3}$ Department of Industrial \& Production Engineering, University of Ibadan, Nigeria.
}

\begin{abstract}
The lack of standard water analysis equipment as well as inadequate trained personnel especially in the developing countries has discouraged many researchers in such countries to execute water quality researches. Hence, this paper presents developed mathematical relationship among some physicochemical parameters in order to aid the determination of the concentrations of certain parameters with the use of minimal equipment. This was achieved by weekly analyzing 7 physicochemical parameters of two sources of potable water (tap water and borehole water) stored in different containers for a period of 6 weeks using standard methods. The storage containers used were black plastic tank, blue plastic tank, green plastic tank, coated steel metal tank, uncoated steel metal tank and clay pot. The parameters examined were turbidity, electrical conductivity (EC), $\mathrm{pH}$, alkalinity, chloride ion $\left(\mathrm{Cl}^{-}\right)$, dissolved oxygen (DO) and total hardness. Results showed that the relationship between electrical conductivity (EC), alkalinity (Alk), total hardness (TH) and chloride ion $\left(\mathrm{Cl}^{-}\right)$is given as; $\mathrm{EC}=-224.8066493+6.244028022(\mathrm{Alk})+0.28204735(\mathrm{TH})+$ $0.000518108\left(\mathrm{Cl}^{-}\right)$. A programing language was written on the models using Visual Basic.Net (VB.Net) version 2018.
\end{abstract}

Keywords: Water, Physicochemical, Parameters, Function, Equation.

\section{INTRODUCTION}

Due to the presence of impurities in the global water resources, only a very few proportion of the world's available water is potable or fit for human consumption (Andrew, 2014; Nala and Jagals, 2013; and Ochekpe, 2011). Knowing the concentrations of the physicochemical and bacteriological parameters of a given sample of water is very important because, comparing the known concentrations with the permissible limits set by regulatory bodies will help in deciding whether such water is potable or not. However, the exact concentration of water quality parameters can only be known by thorough analysis of the water with standard equipment as well as reagents, which could be expensive, time consuming and risky. Hence, it is necessary to develop a means of reducing the time usually spent in analyzing water quality as well as the cost incurred. This could be achieved by building an equation (mathematical model) out of previous studies that will act as a representation of reality without interfering directly with the quality of the result.

Momona Ethiopian Journal of Science (MEJS), V12(1):123-134,2020 @CNCS, Mekelle University, ISSN:2220-184X Submitted on: 01-10-2019

Revised and Accepted on: 13-01-2020 
A mathematical model will actually reduce the risk, cost and also the time spent in analyzing the quality of water samples. A well written programing language of the model will further reduce the time spent when installed in a computer.

The multiple linear regression (MLR) model has been reported to be very useful in modelling factors influencing hydrological parameters such as infiltration and evapotranspiration rates (Patle et al., 2018; Saito et al., 2016; Helder et al., 2016; Rashidi et al., 2014; Shirgure, 2012). Many researchers have used MLR model successfully to determine factors influencing groundwater flow (e.g. Yan et al., 2018; Zomlot et al., 2015; Sahoo and Jha, 2013) and for checking water quality (Mustafa and Fuaad, 2019; Salam et al., 2018; Magda and Marco, 2018; Chen and Liu, 2015; Ahamad et al., 2015; Narayanan et al., 2015). However, the efficacy of this model for potable water quality is not yet studied. Hence, this paper presents the results of the investigation carried out to check the possibility of using MLR model in understanding the relationship between the quality parameters of potable water.

\section{METHODOLOGY}

Tap water obtained from the water treatment plant of the Ahmadu Bello University water works, Zaria (11 $\left.{ }^{\circ} 17.43^{\prime \prime} \mathrm{N}, 7^{\circ} 39^{\prime} 29.43^{\prime \prime} \mathrm{E}\right)$ were filled into disinfected tap-fitted tanks made from coated steel metal, uncoated steel metal, black plastic, green plastic, blue plastic and clay pot having volume of $25 \mathrm{~L}$ each. Another set of these storage tanks were used in storing borehole water obtained at No. 1 Basawa Road, Zaria (11 9'34.96"N, 7³8'59.86"E). Water samples were collected from the storage containers into properly labeled disinfected sample bottles through the taps fitted in the storage containers on a weekly basis (7 days interval). The water filled in the above mentioned containers were stored for a period of six weeks ( 42 days). This storage period and sampling frequency is in agreement with the reports of Ogbozige et al. (2018a); Michael (2015); Henry et al. (2014); and Akulari et al. (2014). The water quality parameters that were monitored includes turbidity, electrical conductivity $(\mathrm{EC}), \mathrm{pH}$, alkalinity, chloride ion $\left(\mathrm{Cl}^{-}\right)$, dissolved oxygen (DO) and total hardness.

The water turbidity was assessed using a turbidimeter (HACH 2100N) made by HANNA LTD, England while pH was determined using a multi-parameter photometer (HI8320) made by HANNA LTD, England. A pocket-sized conductivity meter (TDS \& EC hold, $\pm 2 \%$ ) made by Griffin Company, USA was used in determining electrical conductivity. On the other hand, 
alkalinity and total hardness were analyzed by Acid-Base and EDTA titration methods respectively, while dissolved oxygen was analyzed by Winkler's method. Chloride ion was analyzed by argentometric method in the presence of potassium chromate indicator. All parameters were analyzed in line with the standard methods (APHA, 2012).

The relationship between the water quality parameters was determined through the regression tool for statistical analysis by employing the method of Multiple Linear Regression (MLR) to fit a relationship for the model. The justification for adopting MLR was based on past literatures related to water quality modelling such as Mustafa and Fuaad (2019); Salam et al. (2018); Magda and Marco (2018); Chen and Liu (2015); Ahamad et al. (2015); and Narayanan et al. (2015). The general MLR model is shown in equation (1) as reported in Rajib (2018).

$Y=\beta_{0}+\beta_{1} X_{1}+\beta_{2} X_{2}+\cdots+\beta_{k} X_{k}+e$

Where, $Y$ is the dependent variable, $X_{1}, X_{2}, \ldots, X_{k}$ are independent variables, $\beta_{0}, \beta_{1}, \beta_{2}, \ldots, \beta_{k}$ are the unknown parameters and $e$ is the error associated with estimate of $Y$.

For $n$ observations on $k+1$ variables, equation (1) transforms as shown in equation (2).

$$
Y_{i}=\beta_{0}+\sum_{j=1}^{k} \beta_{j} X_{i, j}+e_{i}
$$

Where $Y_{i}$ is the $i$ th observation of the dependent variable and $X_{i, j}$ is the $i$ th observation of the $j$ th independent variable.

The concept of sum of squares of errors was applied on equation (2) to yield equation (3). Thereafter, the associated error $e$ was minimized by partial differentiation of equation (3) with respect to $\beta_{0}, \beta_{1}, \beta_{2}, \ldots, \beta_{k}$, and equating the values to zero. The resulted equations were transformed into matrix form as shown in equation (4)

$\sum_{i=1}^{n} e_{i}{ }^{2}=\sum_{i=1}^{n}\left(Y_{i}-\beta_{0}-\sum_{j=1}^{p} \beta_{j} X_{i, j}\right)^{2}$

$$
\left[\begin{array}{c}
Y_{1} \\
Y_{2} \\
Y_{3} \\
\vdots \\
Y_{n}
\end{array}\right]=\left[\begin{array}{c}
\beta_{0} \\
\beta_{1} \\
\beta_{2} \\
\vdots \\
\beta_{p}
\end{array}\right]\left[\begin{array}{cccccc}
1 & X_{1,1} & X_{1,2} & X_{1,3} & \cdots & X_{1, k} \\
1 & X_{2,1} & X_{2,2} & X_{2,3} & \cdots & X_{2, k} \\
1 & X_{3,1} & X_{3,2} & X_{3,3} & \cdots & X_{3, k} \\
\vdots & \vdots & \vdots & \vdots & \vdots \\
1 & X_{n .1} & X_{n, 2} & X_{n, 3} & \cdots & X_{n, k}
\end{array}\right]
$$

Equation (4) was solved simultaneously and the obtained values of $\beta_{0}, \beta_{1}, \beta_{2}, \ldots, \beta_{k}$ were substituted in the general MLR model given in equation (1).

The flowchart for the model was drawn using CorelDraw X7 while the programming language for the model was written through Visual Basic.Net (VB.Net) version 2018. It was finally validated using JMP version 14.0. 


\section{RESULTS AND DISCUSSION}

The laboratory results of the 7 physicochemical parameters monitored during the six (6) weeks retention period for both sources of water are shown in table 1.

Table 1. Variation in physicochemical parameters of water during storage period.

\begin{tabular}{|c|c|c|c|c|c|c|c|c|}
\hline $\begin{array}{l}\text { Retention } \\
\text { Time } \\
\text { (Week) } \\
\end{array}$ & $\begin{array}{l}\text { Type of Water } \\
\text { and Storage } \\
\text { Container }\end{array}$ & $\begin{array}{l}\text { Turbidity } \\
\text { (NTU) }\end{array}$ & $\begin{array}{l}E C \\
(\mu S / \mathrm{cm})\end{array}$ & $p H$ & $\begin{array}{l}\text { Alkalinity } \\
(\mathrm{mg} / \mathrm{l} \\
\left.\mathrm{CaCO}_{3}\right) \\
\end{array}$ & $\begin{array}{l}\mathrm{Cl}^{-} \\
(\mathrm{mg} / \mathrm{l})\end{array}$ & $\begin{array}{l}D O \\
(m g / l)\end{array}$ & $\begin{array}{l}\text { Total } \\
\text { Hardness } \\
\left.(\mathrm{mg} / \mathrm{l} \mathrm{CaCO})_{3}\right)\end{array}$ \\
\hline \multirow[t]{2}{*}{0} & $\begin{array}{l}\text { Tap water before } \\
\text { storage }\end{array}$ & 2.000 & 118.99 & 6.6 & 54.01 & 21.04 & 1.5 & 27.61 \\
\hline & $\begin{array}{l}\text { Borehole water } \\
\text { before storage }\end{array}$ & 1.091 & 707.02 & 7.0 & 126.13 & 160.01 & 1.3 & 138.07 \\
\hline \multirow{12}{*}{1} & $\mathrm{BKP}_{\mathrm{t}}$ & 2.08 & 91.01 & 7.0 & 46.00 & 12.53 & 2.0 & 23.04 \\
\hline & $\mathrm{USM}_{\mathrm{t}}$ & 16.07 & 97.98 & 7.4 & 47.99 & 15.00 & 2.0 & 24.00 \\
\hline & $\mathrm{GRP}_{\mathrm{t}}$ & 2.072 & 83.95 & 7.5 & 43.96 & 9.95 & 2.1 & 21.95 \\
\hline & $\mathrm{CSM}_{\mathrm{t}}$ & 1.191 & 105.04 & 7.0 & 51.00 & 16.25 & 2.1 & 24.36 \\
\hline & $\mathrm{BLP}_{\mathrm{t}}$ & 2.210 & 90.96 & 7.1 & 45.95 & 12.51 & 2.0 & 23.01 \\
\hline & $\mathrm{CLP}_{\mathrm{t}}$ & 1.053 & 126.04 & 7.0 & 57.50 & 23.44 & 2.7 & 24.98 \\
\hline & $\mathrm{BKP}_{\mathrm{b}}$ & 0.214 & 637.60 & 7.2 & 130.90 & 157.51 & 2.1 & 197.03 \\
\hline & $\mathrm{USM}_{\mathrm{b}}$ & 6.080 & 626.90 & 8.5 & 129.95 & 154.96 & 2.4 & 186.95 \\
\hline & $\mathrm{GRP}_{\mathrm{b}}$ & 0.209 & 616.05 & 7.3 & 129.01 & 152.58 & 2.4 & 177.50 \\
\hline & $\mathrm{CSM}_{\mathrm{b}}$ & 0.799 & 637.60 & 7.4 & 130.92 & 157.49 & 2.1 & 197.04 \\
\hline & $\mathrm{BLP}_{\mathrm{b}}$ & 0.211 & 644.03 & 7.4 & 131.04 & 160.00 & 1.9 & 205.02 \\
\hline & $\mathrm{CLP}_{\mathrm{b}}$ & 0.219 & 658.08 & 7.1 & 131.99 & 163.66 & 2.6 & 222.48 \\
\hline \multirow{12}{*}{2} & $\mathrm{BKP}_{\mathrm{t}}$ & 1.960 & 108.49 & 8.1 & 52.03 & 18.33 & 1.6 & 24.51 \\
\hline & $\mathrm{USM}_{\mathrm{t}}$ & 12.801 & 108.46 & 8.3 & 51.96 & 17.50 & 1.0 & 24.49 \\
\hline & $\mathrm{GRP}_{\mathrm{t}}$ & 1.731 & 118.98 & 8.2 & 56.00 & 19.98 & 1.4 & 24.95 \\
\hline & $\mathrm{CSM}_{\mathrm{t}}$ & 1.710 & 119.01 & 8.1 & 55.97 & 19.95 & 1.3 & 25.04 \\
\hline & $\mathrm{BLP}_{\mathrm{t}}$ & 1.904 & 125.96 & 8.2 & 57.54 & 22.46 & 1.1 & 25.00 \\
\hline & $\mathrm{CLP}_{\mathrm{t}}$ & 2.001 & 136.46 & 7.8 & 60.02 & 24.97 & 1.4 & 25.06 \\
\hline & $\mathrm{BKP}_{\mathrm{b}}$ & 0.197 & 734.96 & 7.1 & 135.96 & 185.04 & 1.8 & 399.97 \\
\hline & $\mathrm{USM}_{\mathrm{b}}$ & 8.310 & 665.01 & 8.7 & 132.01 & 164.97 & 1.1 & 232.52 \\
\hline & $\mathrm{GRP}_{\mathrm{b}}$ & 0.122 & 728.00 & 7.6 & 136.04 & 182.45 & 1.4 & 374.96 \\
\hline & $\mathrm{CSM}_{\mathrm{b}}$ & 0.142 & 720.95 & 7.2 & 135.02 & 179.92 & 1.3 & 345.02 \\
\hline & $\mathrm{BLP}_{\mathrm{b}}$ & 0.148 & 735.02 & 7.8 & 136.01 & 184.95 & 1.3 & 399.95 \\
\hline & $\mathrm{CLP}_{\mathrm{b}}$ & 0.127 & 664.97 & 7.4 & 132.00 & 165.03 & 1.4 & 232.48 \\
\hline \multirow{10}{*}{3} & $\mathrm{BKP}_{\mathrm{t}}$ & 1.830 & 136.45 & 7.7 & 59.98 & 24.95 & 1.6 & 25.05 \\
\hline & $\mathrm{USM}_{\mathrm{t}}$ & 9.490 & 108.39 & 7.8 & 52.01 & 17.55 & 1.4 & 24.45 \\
\hline & $\mathrm{GRP}_{\mathrm{t}}$ & 1.560 & 87.53 & 8.0 & 45.03 & 11.25 & 2.4 & 22.21 \\
\hline & $\mathrm{CSM}_{\mathrm{t}}$ & 1.410 & 136.51 & 7.6 & 61.06 & 24.99 & 1.7 & 25.09 \\
\hline & $\mathrm{BLP}_{\mathrm{t}}$ & 1.650 & 97.95 & 7.6 & 49.04 & 15.04 & 1.3 & 23.96 \\
\hline & $\mathrm{CLP}_{\mathrm{t}}$ & 0.342 & 118.89 & 7.2 & 55.96 & 19.94 & 1.4 & 24.98 \\
\hline & $\mathrm{BKP}_{\mathrm{b}}$ & 0.303 & 706.97 & 7.0 & 134.02 & 177.46 & 1.3 & 305.04 \\
\hline & $\mathrm{USM}_{\mathrm{b}}$ & 1.290 & 615.99 & 8.1 & 129.94 & 152.48 & 1.3 & 177.52 \\
\hline & $\mathrm{GRP}_{\mathrm{b}}$ & 0.317 & 717.53 & 7.2 & 135.03 & 179.96 & 1.3 & 333.04 \\
\hline & $\mathrm{CSM}_{\mathrm{b}}$ & 0.806 & 706.95 & 6.9 & 133.95 & 177.48 & 1.5 & 305.01 \\
\hline
\end{tabular}




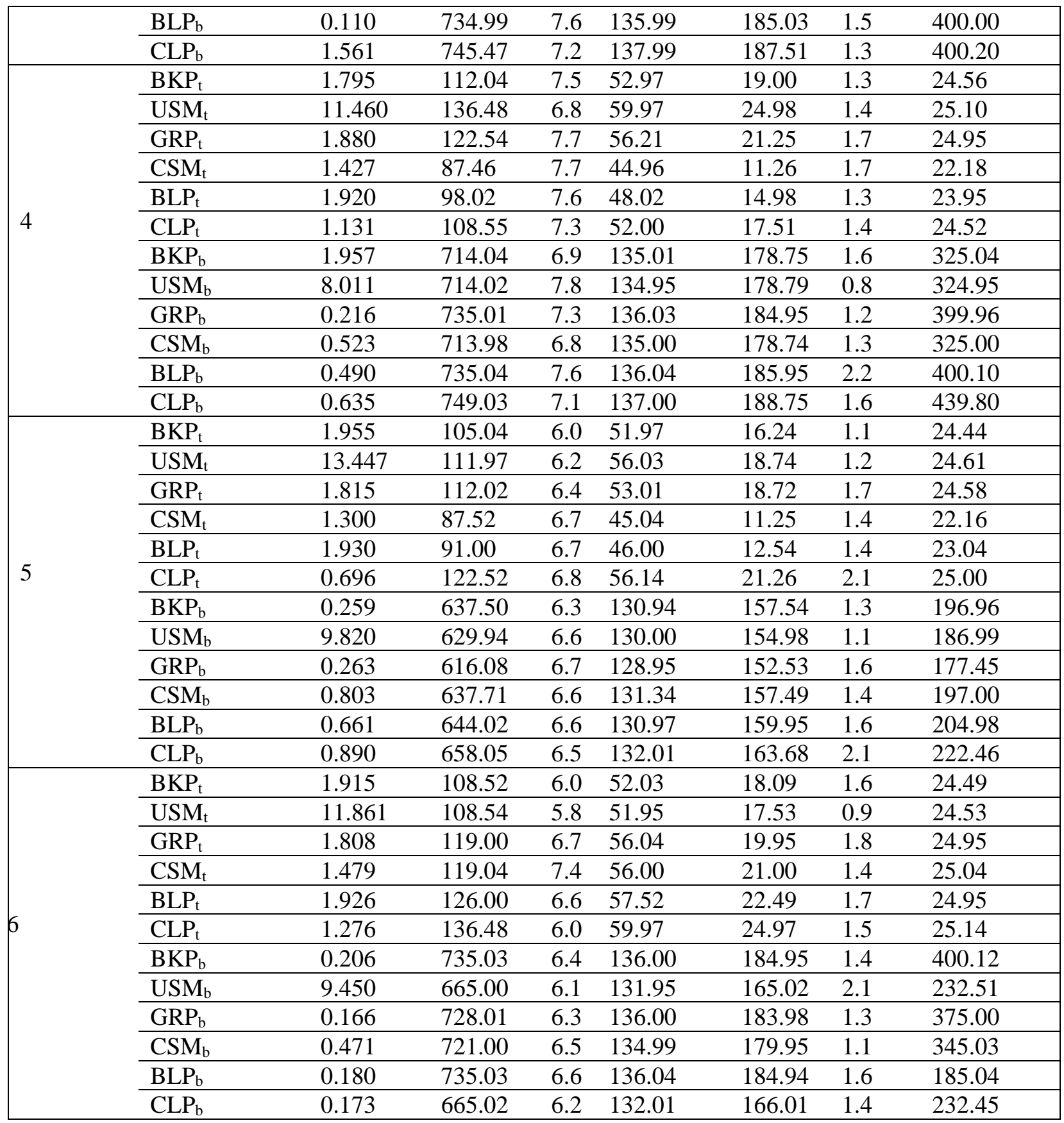

Note: $\mathrm{BKP}_{\mathrm{t}}=$ Tap water stored in a black plastic tank;

$\mathrm{USM}_{\mathrm{t}}=$ Tap water stored in an uncoated steel metal tank;

$\mathrm{GRP}_{\mathrm{t}}=$ Tap water stored in a green plastic tank;

$\mathrm{CSM}_{\mathrm{t}}=$ Tap water stored in a coated steel metal tank;

$\mathrm{BLP}_{\mathrm{t}}=$ Tap water stored in a blue plastic tank;

$\mathrm{CLP}_{\mathrm{t}}=$ Tap water stored in a clay pot while BKP $, \mathrm{USM}_{b}, \mathrm{GRP}_{b}, \mathrm{CSM}_{\mathrm{b}}, \mathrm{BLP}_{\mathrm{b}}$ and CLP represent borehole water stored in corresponding containers 


\subsection{Regression Analysis}

Curves were plotted between the parameters of the results shown in table 1 in a linear graph, and it was observed that the electrical conductivity (EC) was a function of alkalinity (Alk), total hardness $(\mathrm{TH})$ and chloride ion $\left(\mathrm{Cl}^{-}\right)$present in the water samples as represented in equation (5). $E C=f\left(A l k, T H, C l^{-}\right)$

In order to fit a relationship between the dependent variable (EC) and independent variables (Alk, $\mathrm{TH}$ and $\mathrm{Cl}^{-}$), equation (5) was transformed into equation (6) as;

$E C=\beta_{0}+\beta_{1}(A l k)+\beta_{2}(T H)+\beta_{3}\left(C l^{-}\right)$

Where, $\beta_{0}, \beta_{1}, \beta_{2}$ and $\beta_{3}$ are constants.

Assuming the line of best fit in equation (6) is associated with an error $e$, then by applying the concept of Sum of Squares of Errors (SSE) to equation (6), it resulted to equation (7) as follows. $S S E=\sum_{i=1}^{n} e_{i}{ }^{2}=\sum_{i=1}^{n}\left[E C_{i}-\beta_{0}-\beta_{1}\left(A l k_{i}\right)-\beta_{2}\left(T H_{i}\right)-\beta_{3}\left(C l^{-}{ }_{i}\right)\right]^{2}$

The error $e$, was minimized by differentiating equation (7) partially with respect to the constants, $\beta_{0}, \beta_{1}, \beta_{2}$ and $\beta_{3}$ and then equating to zero to produce equations (8), (9), (10) and (11) respectively. That is;

$$
\begin{aligned}
& \frac{\partial \sum_{i=1}^{n} e_{i}^{2}}{\partial \beta_{0}}=2 \sum_{i=1}^{n}\left[E C_{i}-\beta_{0}-\beta_{1}\left(A l k_{i}\right)-\beta_{2}\left(T H_{i}\right)-\beta_{3}\left(C l^{-}{ }_{i}\right)\right][-1]=0 \\
& \frac{\partial \sum_{i=1}^{n} e_{i}{ }^{2}}{\partial \beta_{1}}=2 \sum_{i=1}^{n}\left[E C_{i}-\beta_{0}-\beta_{1}\left(A l k_{i}\right)-\beta_{2}\left(T H_{i}\right)-\beta_{3}\left(C l^{-}{ }_{i}\right)\right]\left[-A l k_{i}\right]=0 \\
& \frac{\partial \sum_{i=1}^{n} e_{i}{ }^{2}}{\partial \beta_{2}}=2 \sum_{i=1}^{n}\left[E C_{i}-\beta_{0}-\beta_{1}\left(A l k_{i}\right)-\beta_{2}\left(T H_{i}\right)-\beta_{3}\left(C l^{-}{ }_{i}\right)\right]\left[-T H_{i}\right]=0 \\
& \frac{\partial \sum_{i=1}^{n} e_{i}{ }^{2}}{\partial \beta_{3}}=2 \sum_{i=1}^{n}\left[E C_{i}-\beta_{0}-\beta_{1}\left(A l k_{i}\right)-\beta_{2}\left(T H_{i}\right)-\beta_{3}\left(C l^{-}{ }_{i}\right)\right]\left[-C l^{-}{ }_{i}\right]=0
\end{aligned}
$$

Equations (8), (9), (10) and (11) were respectively rearranged to obtain equations (12), (13), (14) and (15) as follows:

$$
\begin{aligned}
& n \beta_{0}+\beta_{1} \sum_{i=1}^{n}\left(A l k_{i}\right)+\beta_{2} \sum_{i=1}^{n}\left(T H_{i}\right)+\beta_{3} \sum_{i=1}^{n}\left(C l^{-}{ }_{i}\right)=\sum_{i=1}^{n}\left(E C_{i}\right) \\
& \beta_{0} \sum_{i=1}^{n}\left(A l k_{i}\right)+\beta_{1} \sum_{i=1}^{n}\left(A l k_{i}\right)^{2}+\beta_{2} \sum_{i=1}^{n}\left[\left(A l k_{i}\right)\left(T H_{i}\right)\right]+\beta_{3} \sum_{i=1}^{n}\left[\left(A l k_{i}\right)\left(C l^{-}{ }_{i}\right)\right]=\sum_{i=1}^{n}\left[\left(A l k_{i}\right)\left(E C_{i}\right)\right] \\
& \beta_{0} \sum_{i=1}^{n}\left(T H_{i}\right)+\beta_{1} \sum_{i=1}^{n}\left[\left(T H_{i}\right)\left(A l k_{i}\right)\right]+\beta_{2} \sum_{i=1}^{n}\left(T H_{i}\right)^{2}+\beta_{3} \sum_{i=1}^{n}\left[\left(T H_{i}\right)\left(C l^{-}{ }_{i}\right)\right]=\sum_{i=1}^{n}\left[\left(T H_{i}\right)\left(E C_{i}\right)\right] \\
& \beta_{0} \sum_{i=1}^{n}\left(C l^{-}{ }_{i}\right)+\beta_{1} \sum_{i=1}^{n}\left[\left(C l^{-}{ }_{i}\right)\left(A l k_{i}\right)\right]+\beta_{2} \sum_{i=1}^{n}\left[\left(C l^{-}{ }_{i}\right)\left(T H_{i}\right)\right]+\beta_{3} \sum_{i=1}^{n}\left(C l^{-}{ }_{i}\right)^{2}=\sum_{i=1}^{n}\left[\left(C l^{-}{ }_{i}\right)\left(E C_{i}\right)\right]
\end{aligned}
$$

The values of the summation (i.e. $\sum$ ) constants in equation (12) to (15) were estimated as; $\sum_{i=1}^{n}\left(A l k_{i}\right)=6887.97, \quad \sum_{i=1}^{n}\left(T H_{i}\right)=11302.57, \quad \sum_{i=1}^{n}\left(C l^{-}{ }_{i}\right)=7014.83, \quad \sum_{i=1}^{n}\left(E C_{i}\right)=29564.48$, $\sum_{i=1}^{n}\left(A l k_{i}\right)^{2}=761539.3263, \quad \sum_{i=1}^{n}\left[\left(A l k_{i}\right)\left(T H_{i}\right)\right]=1441780.633, \quad \sum_{i=1}^{n}\left[\left(A l k_{i}\right)\left(\mathrm{Cl}^{-}{ }_{i}\right)\right]=881948.7181$, $\sum_{i=1}^{n}\left[\left(A l k_{i}\right)\left(E C_{i}\right)\right]=3613718.788, \quad \sum_{i=1}^{n}\left(T H_{i}\right)^{2}=3241079.143, \quad \sum_{i=1}^{n}\left[\left(\mathrm{TH}_{i}\right)\left(\mathrm{Cl}^{-}{ }_{i}\right)\right]=1834879.596$, 
$\sum_{i=1}^{n}\left[\left(T H_{i}\right)\left(E C_{i}\right)\right]=7376714.233, \quad \sum_{i=1}^{n}\left(C l^{-}{ }_{i}\right)^{2}=11003624.99 \quad$ and $\quad$ finally, $\quad \sum_{i=1}^{n}\left[\left(C l^{-}{ }_{i}\right)\left(E C_{i}\right)\right]=$ 4453156.08 .

The sample size $n=74$ (Table 1) hence, the numerical values of the summation constants were substituted in equation (12) to (15) in matrix form as shown in equation (16).

$\left[\begin{array}{cccc}74 & 6887.97 & 11302.57 & 7014.83 \\ 6887.97 & 761539.3263 & 1441780.633 & 881948.7181 \\ 11302.57 & 1441780.633 & 3241079.143 & 1834879.596 \\ 7014.83 & 881948.7181 & 1834879.596 & 11003624.99\end{array}\right]\left[\begin{array}{c}\beta_{0} \\ \beta_{1} \\ \beta_{2} \\ \beta_{3}\end{array}\right]=\left[\begin{array}{c}29564.48 \\ 3613718.788 \\ 7376714.233 \\ 4453156.08\end{array}\right]$

The $4 \times 4$ matrix in equation (16) was reduced to Echelon or upper triangular matrix shown in equation (17) using $\mathrm{R}_{1}, \mathrm{R}_{2}, \mathrm{R}_{3}$ and $\mathrm{R}_{4}$ to represent first, second, third and fourth row respectively.

$$
\begin{aligned}
& {\left[\begin{array}{cccc}
74 & 6887.97 & 11302.57 & 7014.83 \\
0 & 120402.4246 & 389729.7805 & 229003.6019 \\
0 & 389729.7808 & 1514753.622 & 763452.4731 \\
0 & 229003.602 & 763452.4729 & 10338654.18
\end{array}\right]\left[\begin{array}{l}
\beta_{0} \\
\beta_{1} \\
\beta_{2} \\
\beta_{3}
\end{array}\right]=\left[\begin{array}{c}
29564.48 \\
861837.0135 \\
2861111.468 \\
1650591.198
\end{array}\right] \rightarrow \begin{array}{c}
\mathrm{R}_{2}-93.08066756 \mathrm{R}_{1} \\
\mathrm{R}_{3}-152.7374324 \mathrm{R}_{1} \\
\mathrm{R}_{4}-94.795 \mathrm{R}_{1}
\end{array}} \\
& {\left[\begin{array}{cccc}
74 & 6887.97 & 11302.57 & 7014.83 \\
0 & 120402.4246 & 389729.7805 & 229003.6019 \\
0 & 0 & 253239.9737 & 22192.28782 \\
0 & 0 & 22192.28803 & 9903092.771
\end{array}\right]\left[\begin{array}{l}
\beta_{0} \\
\beta_{1} \\
\beta_{2} \\
\beta_{3}
\end{array}\right]=\left[\begin{array}{c}
29564.48 \\
861837.0135 \\
71437.16155 \\
11390.15173
\end{array}\right] \longrightarrow \begin{array}{l}
\longrightarrow \\
\mathrm{R}_{3}-3.236893128 \mathrm{R}_{2}
\end{array}} \\
& {\left[\begin{array}{cccc}
74 & 6887.97 & 11302.57 & 7014.83 \\
0 & 120402.4246 & 389729.7805 & 229003.6019 \\
0 & 0 & 253239.9737 & 22192.28782 \\
0 & 0 & 0 & 9903092.771
\end{array}\right]\left[\begin{array}{l}
\beta_{0} \\
\beta_{1} \\
\beta_{2} \\
\beta_{3}
\end{array}\right]=\left[\begin{array}{c}
29564.48 \\
861837.0135 \\
71437.16155 \\
5129.868091
\end{array}\right] \longrightarrow \mathrm{R}_{4}-0.087633432 \mathrm{R}_{3}}
\end{aligned}
$$

The constants $\beta_{0}, \beta_{1}, \beta_{2}$ and $\beta_{3}$ were determined by applying the Gauss - Jordan elimination (backward substitution) method in equation (17) to yield equation (18) to (21).

$$
\begin{aligned}
74 \beta_{0}+6887.97 \beta_{1}+11302.57 \beta_{2}+7014.83 \beta_{3} & =29564.48 \\
120402.4246 \beta_{1}+389729.7805 \beta_{2}+229003.6019 \beta_{3} & =861837.0135 \\
253239.9737 \beta_{2}+22192.28782 \beta_{3} & =71437.16155 \\
9901147.985 \beta_{3} & =5129.868091
\end{aligned}
$$

From (21), $\boldsymbol{\beta}_{3}=\frac{5129.868091}{9901147.98}=\mathbf{0 . 0 0 0 5 1 8 1 0 8}$

From (20), $\boldsymbol{\beta}_{2}=\frac{71437.16155-22192.28782(0.000518108)}{253239.9737}=\mathbf{0 . 2 8 2 0 4 7 3 5}$

From (19), $\boldsymbol{\beta}_{1}=\frac{861837.0135-389729.7805(0.28204735)-229003.6019(0.000518108)}{120402.4246}=\mathbf{6 . 2 4 4 0 2 8 0 2 2}$. Lastly,

From (18), $\boldsymbol{\beta}_{0}=\frac{29564.48-6887.97(6.244028022)-11302.57(0.28204735)-7014.83(0.000518108)}{74}=\mathbf{- 2 2 4 . 8 0 6 6 4 9 3}$

Substituting the values of constants $\beta_{0}, \beta_{1}, \beta_{2}$ and $\beta_{3}$ into equation (6) yields equation (22).

$E C=-224.8066493+6.244028022(A l k)+0.28204735(T H)+0.000518108\left(C l^{-}\right)$ 


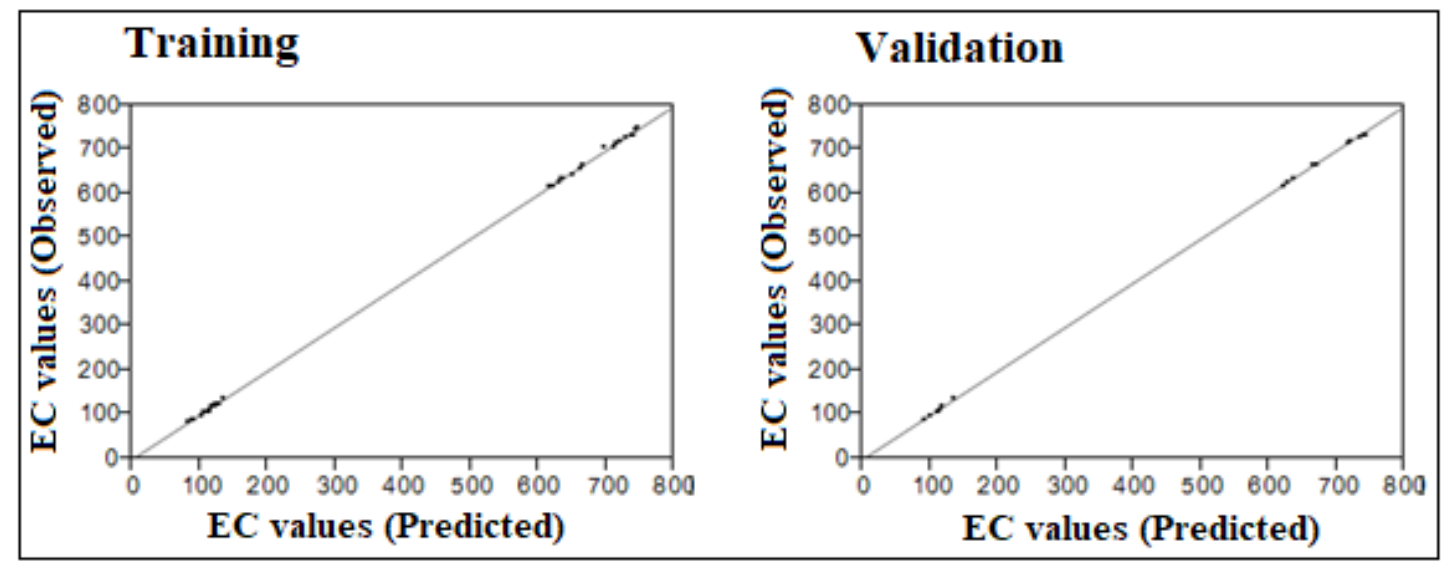

Figure 1. Comparism of EC $(\mu \mathrm{S} / \mathrm{cm})$ between observed and predicted values.

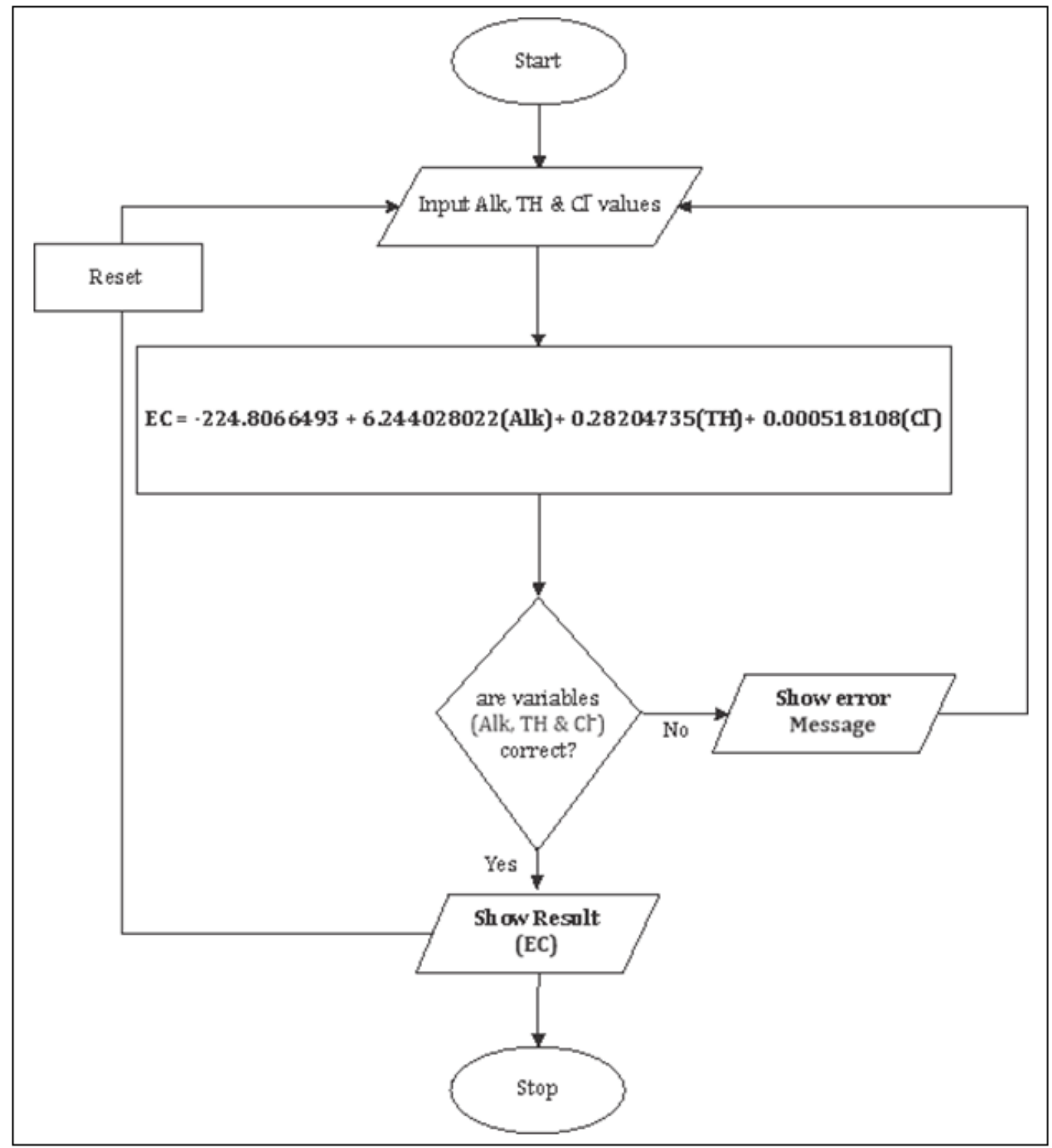

Figure 2. Flowchart of computer program. 
Equation (22) is the general model relating the electrical conductivity (EC), alkalinity (Alk), total hardness $(\mathrm{TH})$ and chloride ion $\left(\mathrm{Cl}^{-}\right)$in the water samples used and it coincides favorably with the experimental values. This was validated by plotting actual values obtained in the field against the predicted values obtained from the regression equation using the same scale via JMP version 14.0 as shown in figure 1. Since most of the plotted points fell on the diagonal of figure 1 , it suggests that the regression equation is highly reliable.

A programming langauge was written for equation (22) using Visual Basic. Net (VB. Net) version 2018 and the flowchart of the model is shown in figure 2.

\subsection{Trend in Water Quality During Retention Period}

The turbidity of both water sources (tap water and borehole water) in all the storage containers during the retention period were within the WHO permissible limit (5.00 NTU) except for water stored in uncoated steel metal tanks (USM $\mathrm{Un}_{\mathrm{t}}$ and $\mathrm{USM}_{\mathrm{b}}$ ). Likewise, the $\mathrm{pH}$ of all the water samples were within the WHO limit $(6.5-8.5)$ in the first four weeks of storage thereafter, little deviations from the permissible limit occurred especially for the water samples stored in uncoated steel metal tanks. The electrical conductivity, chloride ion and alkalinity of the water samples throughout the retention period were within the WHO standards ( $750 \mu \mathrm{S} / \mathrm{cm}, 200 \mathrm{mg} / \mathrm{l}$ and $250 \mathrm{mg} / \mathrm{l}$ respectively) irrespective of the type of water and storage container. Dissolved oxygen (DO) is an important water quality parameter as it is a respiratory gas. The DO content in all the water samples improved (increased) during the first week of storage and afterward, it fluctuated between values higher and lower than the permissible limit $(1.5 \mathrm{mg} / \mathrm{l})$. Notwithstanding, the minimum concentration of DO $(1.0 \mathrm{mg} / \mathrm{l})$ was recorded on the second week of retention in tap water stored in uncoated steel metal tank (USM $)_{t}$ while the maximum concentration $(2.7 \mathrm{mg} / \mathrm{l})$ was noted on the first week in tap water stored in clay pot $\left(\mathrm{CLP}_{\mathrm{t}}\right)$. The variations in hardness (total) level of the water samples during the retention period were not much. Nevertheless, water samples drawn from storage containers filled with borehole water recorded higher concentrations ( $308.77 \mathrm{mg} / \mathrm{l}$ to $661 \mathrm{mg} / \mathrm{l})$ than samples drawn from storage containers filled with tap water $(77.44 \mathrm{mg} / \mathrm{l}$ to $127.60 \mathrm{mg} / \mathrm{l})$. Water hardness above $200 \mathrm{mg} / \mathrm{l}$ may cause scale deposition in treatment works and pipe distribution system as well as excessive soap consumption (Ogbozige et al., 2018b). 


\section{CONCLUSION}

Based on the results obtained in this research, it could be concluded that the relationship between electrical conductivity (EC), alkalinity (Alk), total hardness (TH) and chloride ion $\left(\mathrm{Cl}^{-}\right)$is given as; $\mathrm{EC}=-224.8066493+6.244028022(\mathrm{Alk})+0.28204735(\mathrm{TH})+0.000518108\left(\mathrm{Cl}^{-}\right)$. Hence, prospective researchers on water quality of the selected sampling points could make use of the model while researchers on water samples drawn from other sources should calibrate the model before making use of it.

\section{ACKNOLEDGEMENTS}

The role played by Prof. O.J. Mudiare in writing this paper is well appreciated.

\section{CONFLICT OF INTERESTS}

There is not conflict of Interests.

\section{REFERENCE}

Ahamad, K.U., Nazary, B.K., Mudoi, P., Rani, R., Bharati, V \& Singh, H. 2015. Application of Regression Analysis for Surface Water Quality Modeling. IOSR Journal of Mechanical and Civil Engineering, 1(1): 65-70.

Akulari, D.D., Steven, T \& Gbenga, A.O. 2014. Effects of Short Term Storage on Water Quality. Nigerian Journal of Science, 30(2): 147-152.

Andrew, F. 2014. Water Quality Deterioration: A Study of Household Drinking Water Quality in Rural Honduras. International Journal of Environmental Health Research, 14(4): 273-284.

APHA. (2012). Standard Methods for Examination of Water and Wastewater (25 ${ }^{\text {th }}$ Edition). American Public Health Association, Washington DC, USA.

Chen, W \& Liu, W. 2015. Water Quality Modelling in Reservoirs Using Multivariate Linear Regression and Two Neural Network Models. Advances in Artificial Neural Systems, 1(1): 31-40.

Helder J. F., Marconio S. S., Jório, B. C \& Maria H. C. 2016. Modeling of reference evapotranspiration by multiple linear regression. Journal of Hyperspectral Remote Sensing, 6(2): 44-58. 
Henry, C.I., Chioma, D.E \& Clifford, M.K. 2014. Water Quality Behavior Over Time. Journal of Tropical Scientific Research, 5(10): 38-50.

Magda, M \& Marco, C. 2018. A Time Series Model Comparison for Monitoring and Forecasting Water Quality Variables. Hydrology, 5(37): 1-20.

Michael, F.P. 2015. Effects of Containers and Storage Conditions on Bacteriological Quality of Borehole Water. Nigeria Journal of Pure and Applied Science, 17(2): 1223-1226.

Mustafa, A \& Fuaad, A. 2019. Modeling Water Quality Parameters Using Data-Driven Models, a Case Study Abu-Ziriq Marsh in South of Iraq. Hydrology, 6(24): 1 - 17.

Nala, N \& Jagals, P. 2013. The Effect of a Water-Hygiene Educational Programme on the Microbiological Quality of Container-Stored Water in Households," Water SA, 29(2): 171176 (DOI: 10.4314/wsa.v29i2.4852).

Narayanan, C. V., Dileep Kumar, P.G \& Ammad, K. K. 2015. Statistical Analysis of Quality of Water in Various Water Shed for Kozhikode City, Kerala, India. Aquatic Procedia, 4: 10781085 (doi: 10.1016/j.aqpro.2015.02.136).

Ochekpe, S.R. 2011. Potability of Nigerian Sachet Water. Daily Trust News Paper, Kaduna, Nigeria. December $6^{\text {th }}$, pp 8-9.

Ogbozige, F.J., Ibrahim, F.B \& Adie, D.B. 2018a. Effect of Storage Time and Container Material on Potable Water Quality. Ife Journal of Science and Technology, 1(2): 59-71.

Ogbozige, F.J., Ibrahim F.B \& Adie, D.B. 2018b. Drinkable Water Stored in Hot Climates: Interactions among Water Quality Parameters. Arid Zone Journal of Engineering, Technology and Environment, 14(3): 381-390.

Patle, G.T., Sikar, T.T., Rawat, K.S \& Singh, S.K. 2018. Estimation of Infiltration Rate from Soil Properties Using Regression Model for Cultivated Land. Geology, Ecology and Landscapes, 1(1):1-14.

Rajib, M. 2018. Statistical Methods in Hydrology and Hydroclimatology. Springer Transactions in Civil and Environmental Engineering, 444p (DOI: 10.1007/978-981-10-8779-0).

Rashidi, M., Ahmadbeyki, A \& Hajiaghaei, A. 2014. Prediction of Soil Infiltration Rate Based on Some Physical Properties of Soil. American-Eurasian J. Agriculture and Environmental Science, 14 (12): 1359-1367. 
Sahoo, S \& Jha, M.K. 2013. Groundwater-Level Prediction Using Multiple Linear Regression and Artificial Neural Network Techniques: A Comparative Assessment. Hydrogeology Journal 21(8): 1865-1887 (DOI 10.1007/s10040-013-1029-5).

Saito, T., Yasuda, H., Suganuma, H., Inosako, K., Abe, Y \& Kojima, T. 2016. Predicting Soil Infiltration and Horizon Thickness for a Large-Scale Water Balance Model in an Arid Environment. Water, 8(3) 96: 1-15 (https://doi.org/10.3390/w8030096).

Salam, H.E., Abed, S.A \& Khadum, S.A. 2018. Predicting the Tigris Water Quality within Baghdad, Iraq by Using Water Quality Index and Regression Analysis. Environmental Technology and Innovation, 11(1): 390-398.

Shirgure, P.S. 2012. Evaporation Modeling with Multiple Linear Regression Techniques - A Review. Scientific Journal of Review, 1(5): 170-182.

Yan, S., Yu, S., Wu, Y., Pan, D \& Dong, J. 2018. Understanding Groundwater Table Using Statistical Model. Water Science and Engineering, 11(1): 1-7.

Zomlot, Z., Verbeiren, B., Huysmans, M \& Batelaan, O. 2015. Spatial Distribution of Groundwater Recharge and Base Flow: Assessment of Controlling Factors. Journal of Hydrology: Regional Studies, 4(4): 349-368. 